\title{
\begin{tabular}{|l|l|l|l}
\hline 学位の種類 & 博士(医学) & 氏名 & 村山賢起 \\
\hline
\end{tabular}
}

\author{
学位論文題目
}

Effects of neurosteroid $3 \alpha$-hydroxy-5 $\alpha$-pregnan-20-one on ethanol-mediated paired-pulse depression of population spikes in the CA-1 region of rat hippocampal slices (ラット海馬スライス CA-1 領域においるコタノールによる集合電位の 2 回刺激抑制に 神経ステロイド3alpha-hydroxy-5alpha-pregnan-20-oneが及ぼす影響)

共著者名 Zorumski F Charles、Izumi Yukitoshi

揭載雑誌名 Neuroscience Letters 394 巻 28 頁一32 頁 2006 年 2 月

研塋目的

中枢神経系に敌いてエタノールがGABA(A)受容体を介する抑制性の作用を増強すること が数多くの報告より知られている。しかし、脳スライスでこれを観察すると臨床で報告さ れているエタノール血中濃度よりもはるかに高い濃度が必要となる。このことはエタノー ルの作用発現に、これを促進する内因性の物質が関与し、生体外の害験系では欠如してい る可能性を示唆する。内因性神経ステロイドの一つである $3 \alpha$-hydroxy-5 $\alpha$-pregnan-20-one

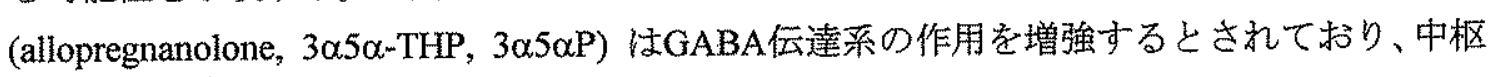
神経系でのエタノールの作用にも関与している可能性が考えられた。そこで我タは中枢神

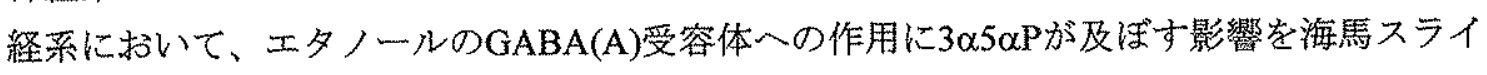
スで検討した。

$$
\text { 材料. 方 法 }
$$

1. ラット海馬スライスの作成

Sprague-Dawley系雄性ラット（30日）を対象に、ハロセン吸入腇酔下で断頭した。脳を頭 蓋内より取り出し、95\%酸素5\%二酸化炭素でバブリングした氷泠下人工脳帮䯣液（ACSF） のなかで、バイブロトームを使用し、500 $\mu \mathrm{m}$ の厚さの海馬スライスを作成した。各々のス 
ライスは、95\%酸素5\%二酸化炭素で飽和させたACSF入りの溶液で2時間潅流させた。

2. 細胞外電位記録法

海馬スライスを、95\%酸素5\%二酸化炭素で飽和させたACSFで浸されているチェンバー 内に載せ固定した。チェンバー内の温度は $30^{\circ} \mathrm{C}$ 設定した。ACSFはチェンバー内を $2 \mathrm{~m} / \mathrm{h}$ で灌流させた。CA3の軸索であるSchafferの側枝が走行する放線層に刺激電極を配置した。

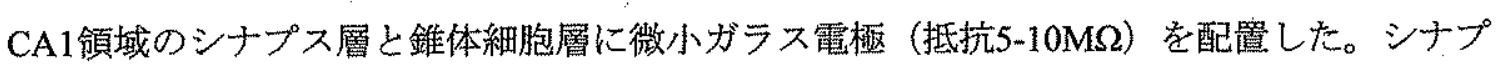
ス層から興奮性シナプス後電位（dEPSP）、錐体細胞層から集合電位 (PS) と細胞体興舊性 シナプス後電位（sEPSP）をそれぞれ同時に記録した。

3. paired-pulse stimulation（2回連続電気刺激）法

刺激は $21 \mathrm{~ms}$ 間隔による連続2回電気刺激法(paired-pulse stimulation)で行いこれを1回の記 録とした。入出力関係を検討するために刺激強度を徐々に変化させ、少なくとも7回以上

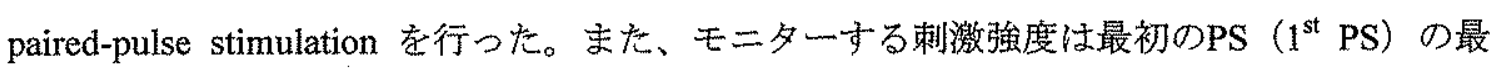
大值の50-60\%に設定した。

\section{4. 薬物}

エタノールの濃度は60mM とし、20分間潅流した。3 $25 \alpha \mathrm{P}$ 濃度は100nMとし、エタ， 一ル投与2時間前に添加した。GABA(A)受容体拮抗薬であるピクロトキシンの濃度は $1 \mu \mathrm{M} と$ した。

\section{5. 統計}

結果は、平均士標準誤差で表した。統計処理は 2 群比較にはStudent t-test、或いは、Man $n$-Whitney U testを用い $\mathrm{p}<0.05$ を有意とした。

成 績

1. dEPSP, SEPSP, PSそれぞれの解析

コントロールのスライスではpaired-pulse stimulationにより、最初のdEPSPに対する2回目

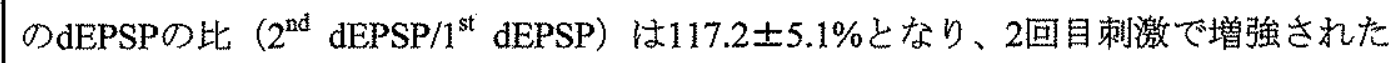
(paired-pulse facilitation; PPF)。最初のSEPSPに対する2回目のSEPSPの比 $\left(2^{\text {nd }} \mathrm{sEPSP} / 1^{\text {st }} \mathrm{sEPSP}\right)$ は51.7士6.7\%となり2回目刺激で抑制された（paired-pulse depression; PPD）。また、最初のPSに対する2回目のPSの比 $\left(2^{\text {nd }} \mathrm{PS} / 1^{\text {st }} \mathrm{PS}\right)$ も $13.3 \pm 5.9 \%$ と、2回目刺激で抑制された（PPD）。 
2. $60 \mathrm{mM}$ エタールルよる影響

上記1のスライスに60mMのエタノールを20分灌流させた後、paired-pulse stimulationを 行った。その結果、 $2^{\text {nd }} \mathrm{dEPSP} / 1^{\text {st }} \mathrm{dEPSP}$ は $115.7 \pm 2.5 \% 、 2^{\text {nd }} \mathrm{sEPSP} / 1^{\text {st }} \mathrm{sEPSPは58.7 \pm 10.0 \% 、}$ $2^{\text {nd }} \mathrm{PS} / 1^{\text {st }}$ PSは21.4 $14.4 \%$ ありもこの三者をそれぞれ上記 1 と比較しても有意差はなかっ た。

3. ピクロトキシンの効果

GABA(A)受容体拮抗薬であるピクロトキシンを投与するとPSでのPPDが阻止されるとい う報告があり、我々の実験でも同様の結果が得られた。この現象はPSにおけるPPDに GABA(A)受容体が関与していることを示している。

4. $3 \alpha 5 \alpha \mathrm{P}$ 効果

次にエタノール投与 2 時間前から $3 \alpha 5 \alpha \mathrm{P} 100 \mathrm{nM}$ 持続添加し、エタノール投与前後の記録

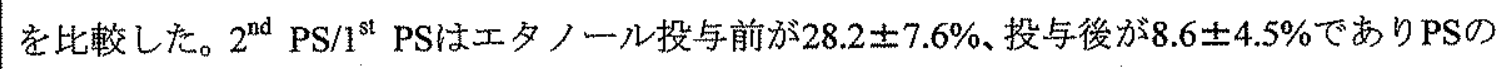
PPDは增強された $(\mathrm{P}<0.01)$ 。しかし、AEPSPのPPFとsEPSPのPPDには有意差は認められな

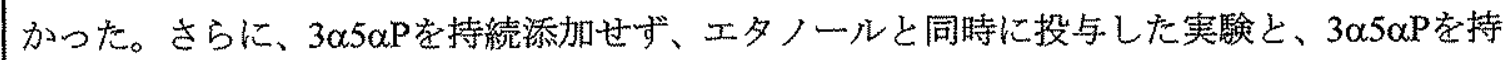
続添加しエタノールを $20 \mathrm{mM}$ で施行した実験では、どちらもPSのPPDが増強されることはな く、有意差を認めなかった。

5. $\mathrm{GABA}(\mathrm{A})$ 受容体の関与

$3 \alpha 5 \alpha \mathrm{P}$ 持続添加によるエタノール $60 \mathrm{mM}$ でのPSのPPD增強が、GABA(A)受容体を介してい

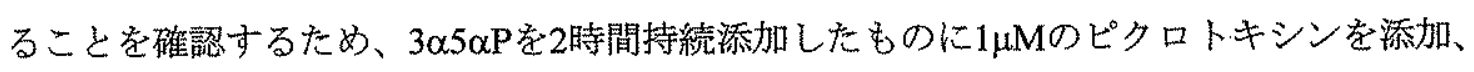
その後エタノールを投与した。その結果エタノール投与前の $2^{\text {nd }}$ PS $/ 1^{\text {st }}$ PSは $86.9 \pm 14.6 \%$ こ

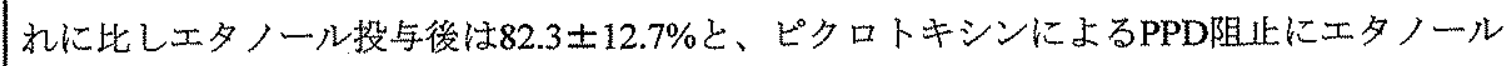
投与による変化は䜀められなかった。

6. $\beta$-サイクロデキストリンの効果

エタノールによるPSのPPD増強に3 $\alpha 5 \alpha \mathrm{P}$ 持続添加が必要であることを確認するため、 $3 \alpha 5 \alpha \mathrm{P}$ の拮抗薬であるß-サイクロデキストリン(ADVASEP-7 $\left.{ }^{\mathrm{R}}\right)$ を用いた実験を行った。この 実験では $3 \alpha 5 \alpha \mathrm{P}$ を2時間持続添加したものにエタノールとADVASEP-7雨者を同時投与した。

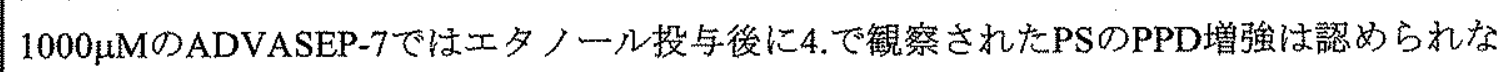

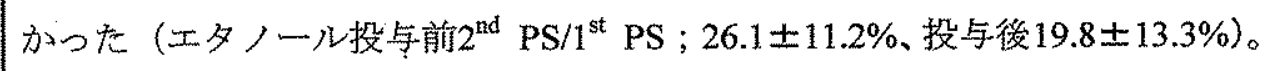

考

案

本研究では、ラット海馬スライスCA-1領域においてエタノール、3 $30 \alpha \mathrm{P}$ のいずれかを投 
与するのみではPSに変化を及ぼすことはなく、雨者の存在で明らかなPPDの増強が認めら れることを示した。最近の報告では $3 \alpha 5 \alpha \mathrm{P}$ は中枢神経系で作用する重要なGABA modulator であるといわれている。また、ラットにエタノールを投与すると $3 \alpha 5 \alpha \mathrm{P}$ 血中濃度は上昇す るといら報告もある。これらの報告は、生体外でエタノールの効果を観察する実験を行う 際、3 $05 \alpha \mathrm{P}$ 方不可欠なホルモンの一つであることが示唆された我々の赛験結果にも矛盾しな いものである。神経ステロイドは生体外で海馬スライスを作成した時点から直ちに消失す る、可能性があり、実験に使用するACSFへの添加の必要性が示晙された。

$3 \alpha 5 \alpha \mathrm{P}$ 存在下、エタノールはPSに就いてのみPPDを増強した (1)が、 dEPSPのPPFに変 化はなく(2))、sEPSPのPPDにも変化はなかった（3)。(2)からはCA-1領域へのグルタミン 酸によるシナプス伝達に変化がないこと、(3)からは樹状突起から細胞体への興奮性の伝達 に変化がないことが示される。一方(1)により、エタノールはシナプス後の錐体細胞領域で、 細胞体自身の興舊性を変化させていることが示晙された。

$$
\text { 結 論 }
$$

生体外でエタノールの中枢神経㧕制効果索観察する際に神経ステロイド $3 \alpha 5 \alpha \mathrm{P}$ 必要なホ ルモン因子の一つと考えられた。

\section{引用 文 献}

1. R. Rupprecht, Neuroactive steroids: mechanisms of action and neuropsychopharmacological properties, Psychoneuroendocrinology 28 (2003) 139-168.

2. R.A. Deitrich, T.V. Dunwiddie, R.A. Harris, V.G. Erwin, Mechanism of action of ethanol: initial central nervous system actions, Pharmacol. Rev, 41 (1989) 489-537.

3. C.L. Faingold, P. N'Gouemo, A. Riaz, Ethanol and neurotransmitter interactions-from molecular to integrative effects, Prog. Neurobiol. 55 (1998) 509-535. 
学位論文の審查結果の要旨

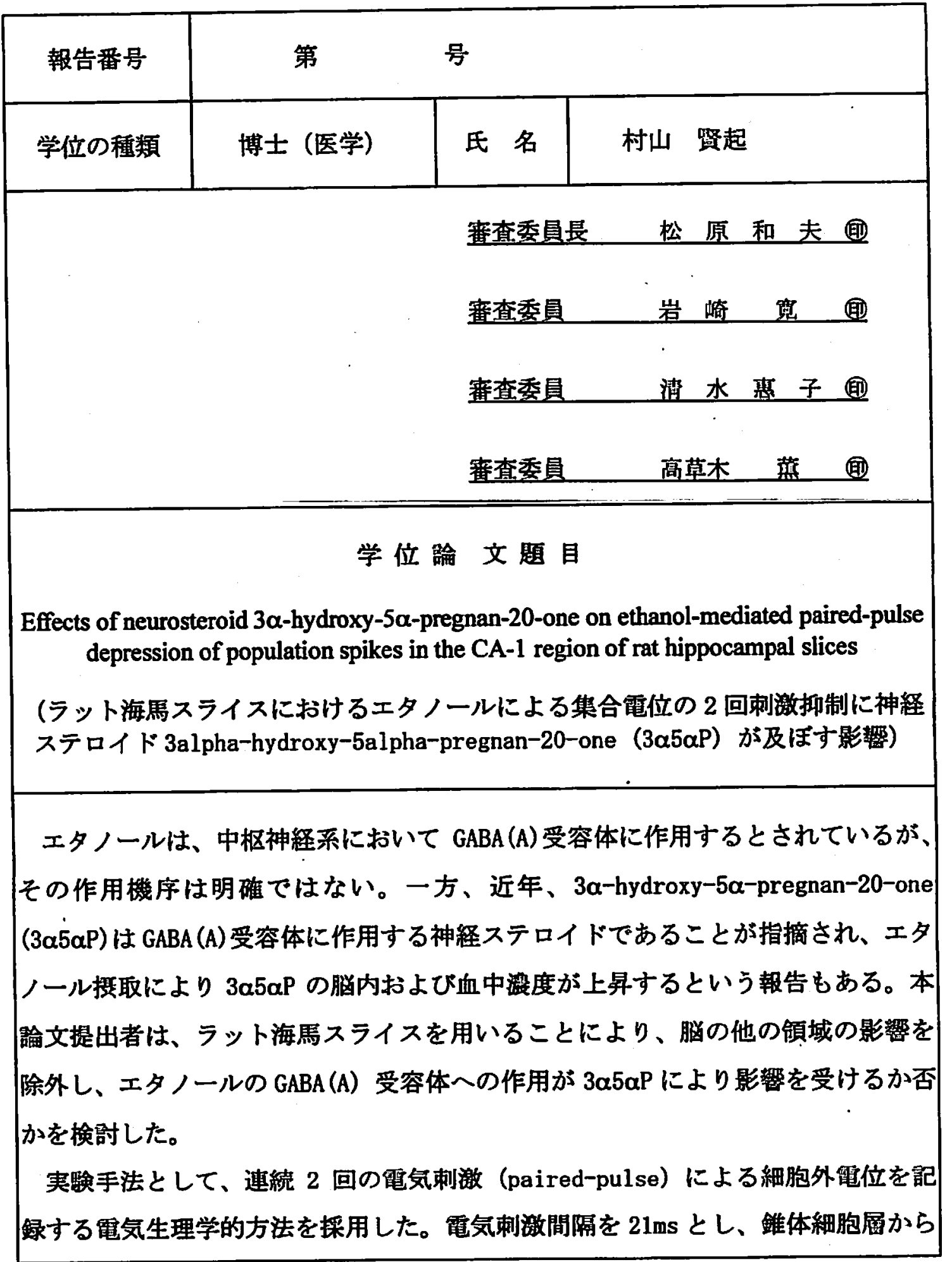




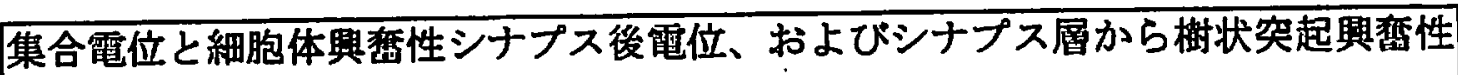
シナプス後電位を同時に記録した。

その結果、60 mM のエタノール単独投与では、投与前後で 2 回目刺激の集合電 位の減少、即ち 2 回刺激抑制は変化しない。しかし、3a5aP に 2 時間暴露したス ライスでは、エタノール存在下、集合電位の 2 回刺激抑制は著明に増強された。

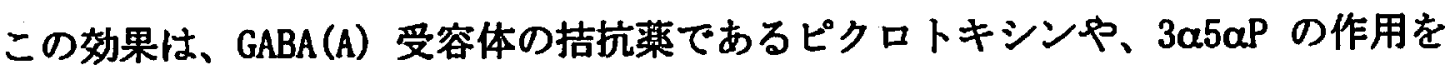
阻害するとされている ADVASEP-7 の存在下では観察されなかった。一方、同時に 記録した樹状突起興㷱性シナプス後電位と細胞体興炭性シナプス後電位において は、エタノール存在下における有意な変化は認められなかった。これらの結果か ら、エタノールの中枢神経系抑制効果発現において $3 \alpha 5 \alpha \mathrm{P}$ が GABA (A) 受容体を介 しその効果を增强すること、これに関与する $\mathrm{GABA}(\mathrm{A})$ 受容体は細胞体付近に存在 することが示された。

本研究は、エタノールの神経細胞への作用が神経ステロイドを介していること を細胞レベルで示唆する新規の知見である。本研究の成果は、神経ステロイドの 役割を明確にすることによって、臨床における GABA (A) 受容体作動性薬戍の新た な展開、進展に大きく貢献し得ると考えられる。なお、各審査委員より、本論文 ならびに関連分野に関する試問の結果からも適切な解答が得られた。よって、審 查委員会は、本踚文が学位論文に十分值するものと判定致した。 